\title{
A INVASÃO DO COTIDIANO EM O INVASOR: música popular como referente legitimador do "real"
}

\author{
THE INVASION OF EVERYDAY LIFE IN THE TRESPASSER: \\ popular music as legitimized referent of "reality"
}

\author{
SUZANA RECK MIRANDA ${ }^{1}$ \\ JOÃO HENRIQUE T. TEREZANI ${ }^{2}$
}

Resumo: Este artigo discute o uso da música popular como um dos instrumentos que, ao acionar referentes que permeiam o cotidiano de forma direta, colabora com a representação da "realidade" em produtos audiovisuais que se inscrevem no campo da ficção. Como suporte a esta abordagem, o estudo destaca aqui o uso específico do rap no filme O Invasor (2001), de Beto Brant. Entre os autores utilizados para subsidiar nossa análise estão Anahid Kassabian e Jeff Smith.

Palavras-Chave: música popular no cinema, trilha musical, rap, Beto Brant.

Abstract: This paper argues about the use of popular music as a tool that collaborates in representing the "reality" in fiction films by evoking everyday life referents. The approach was based in ideas developed by authors as Anahid Kassabian and Jeff Smith, together with an analysis of the specific use of rap in Beto Brant's The Trespasser (2001).

Keywords: popular music in films, film music, rap, Beto Brant.

\footnotetext{
${ }^{1}$ Professora Doutora do Departamento de Artes e Comunicação e do Programa de Pós-Graduação em Imagem e Som, ambos da UFSCar, onde ainda coordena o Grupo de Estudos do Som e da Música no Audiovisual (GESOMA). Publicou vários artigos e capítulos de livros sobre a relação da música com outros meios, em especial com o cinema. Instituição: UFSCar. e-mail: suzana@ufscar.br

${ }^{2}$ Mestrando no Programa de Pós-Graduação em Imagem e Som da UFSCar, onde desenvolve pesquisa sobre a configuração narrativa do silêncio no cinema de Júlio Bressane. Integrante do Grupo de Estudos do Som e da Música no Audiovisual (GESOMA). Instituição: UFSCar. e-mail: joao.henriq@gmail.com
} 


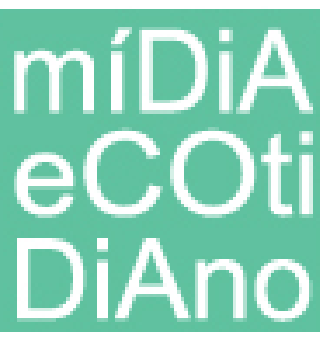

PPGMC

Introdução

De acordo com Heller, a vida cotidiana está fartamente carregada de possibilidades, o que coloca a escolha como uma situação imperativa e constante. Para a autora, são escolhas que tanto podem ser moralmente motivadas, como não. No entanto, quanto mais complexas implicações morais uma escolha trouxer, mais a decisão se eleva da "cotidianidade e tanto menos se pode falar de uma decisão cotidiana" (HELLER, 2008, p. 39). Esta situação pode ser facilmente identificada em $O$ Invasor (Beto Brant - 2001), um filme cujo enredo carrega a tensão da escolha. E, se concordarmos com Heller, Brant acrescenta uma situação peculiar se pensarmos a obra a partir do ponto de vista dos personagens: enquanto para os bem-nascidos Ivan (Marco Ricca) e Giba (Alexandre Borges), suas escolhas, aparentemente, estão absurdamente longe do cotidiano que vivem, para Anísio (Paulo Miklos), originário da “periferia”, sua movimentação e decisões são colocadas como rituais banais do seu dia-a-dia.

Esta seria uma primeira leitura de um enredo construído com personagens delimitados social e espacialmente no início do filme. Ivan, Giba e Estevão (Gilberto Freire) são empresários da construção civil e circulam pelo território onde estão instalados os detentores de riqueza da metrópole São Paulo. Distantes, portanto, segundo a fantasia da alta classe média paulistana - dos códigos e movimentos da periferia. Não fosse um detalhe: Giba e Ivan conhecem os percursos ilícitos que agregam mais riqueza a quem já tem. Querem investir nesta vereda, mas os pruridos morais (ou receios da punição) colocam Estevão de outro lado, discordando da dupla. É a partir deste confronto, que mobiliza, inicialmente, o que parece ser uma escolha muito distante de Giba e Ivan, que o filme traz à cena Anísio: trata-se da classe média, como sempre, solicitando os préstimos dos “trabalhadores" da periferia.

Deslizando pelos dois mundos em um percurso que explicita uma sociedade urbana caótica, com muros construídos apenas como fortalezas aparentes - pois que corrompidos pelo vale-tudo dos dois lados que separa periferia e alta classe média paulistana - O Invasor não se intimida pelas brechas do non sense que ronda seu enredo em muitos momentos. Apostando na estratégia do gênero, o diretor faz os sócios Ivan e Giba degringolarem a partir da decisão de contratar o matador de aluguel. Anísio não só 


\section{míDiA

executa o serviço como passa, a partir daí, a inverter o jogo: de contratado e mandado, orquestra uma nova relação, dando as cartas a partir de então. No modelo que decide implantar, é ele agora quem tem o poder enquanto Ivan e Giba, acuados, buscam fórmulas para liquidá-lo.

Ao embaralhar as moralidades e mergulhar o filme - e o espectador - em um universo caótico, pautado pelas regras e códigos do que chamamos “mundo cão”, o invasor também precisa que os territórios plasticamente deformados não se distanciem, demais, dos indicadores que garantem verossimilhança à narrativa. Anísio, o sapo marginal atrai a bela princesa Marina (Mariana Ximenes), filha de Estevão, para o seu mundo, graças à construção da personagem calcada no estereótipo de uma juventude alienada, hedonista que encontra nas drogas e nas baladas um prazer que não toca em seu mundo. Com a conquista de mais este troféu, Anísio entranha-se mais fundo no espaço dos empresários, deslocando-os drasticamente para o seu universo moral, e sobrelevando a tensão “centro x periferia”. As locações que, em vórtice, carregam rapidamente o espectador do ambiente da elite social à favela, reforçam uma ilustração emblemática dos conflitos sociais e espaciais que as grandes cidades brasileiras, como São Paulo, enfrentam.

Nossa proposta é refletir sobre como a trilha musical de $O$ Invasor, apoiada em um uso consciente da música popular, atua na construção narrativa como um todo, tanto na conformação das relações sociais e espaciais representadas na diegese quanto na tradicional constituição de "afetos", característica comumente atribuída ao uso da música no cinema. Nomes como Pavilhão 9, Tolerância Zero, Professor Antena, Instituto e Sabotage compõem a compilação musical utilizada, sendo este último, além de responsável por boa parte das canções, um personagem do filme.

Vale assinalar, resgatando rapidamente o uso da música no cinema, que há uma espécie de consenso de que uma de suas principais funções, desde o período silencioso, é evocar, sublinhar e suscitar emoções no espectador. Seja via uma música originalmente composta para um filme ou na utilização de um repertório pré-existente, esteja ela na diegese (como execução musical filmada e/ou execução musical encenada), 


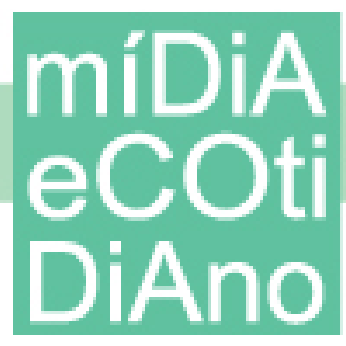

ou como música de fundo, sempre é possível, se for o objetivo, lidar com uma espécie de conteúdo emocional.

Em relação a $O$ Invasor, Kátia Maciel, em relevante ensaio dedicado ao mesmo tema, recortou sua reflexão em torno de mediações culturais motivadas pelas referências musicais e pela participação de Paulo Miklos (cantor e compositor) e de Sabotage (rapper) tanto como atores quanto como "autores" de parte da trilha musical do filme. Entre outras coisas, a autora apontou que esta simbiose autor/ator tem sido uma característica recorrente em vários filmes brasileiros recentes (MACIEL, 2010).

O fato é que a trilha musical do filme, como já dito, apresenta conotações políticas e sociais evidentes e não atua, como ocorre em tantas obras, apenas como pano-de-fundo. Trabalhada, portanto, como componente essencial à narrativa, nosso recorte, aqui, foca a presença do rap no filme e os múltiplos aspectos que tal interface oferece. Nosso intuito, sobretudo, é de que esta breve análise em torno de um gênero musical identificado como presente em determinado cotidiano, contribua para a reflexão sobre as especificidades que envolvem o uso e as funções da música popular no cinema.

\section{Mídia alimenta mídia}

“O cinema não é apenas um mostrador de sons e imagens, mas gera também sensações rítmicas, dinâmicas, temporais, táteis e cinéticas, que usam indiferentemente os canais sonoro e visual”, lembra Chion (2008, p. 120). Uma constatação que o autor articula às mudanças provocadas pelas transformações técnicas que ampliam a sensorialidade, o que era particularmente caro a determinados cineastas dos anos 1920 (Eisenstein, Epstein, entre outros) interessados em experiências estéticas oriundas dos avanços técnicos. Em relação ao som, há o grande marco da sua conquista que abriu, evidentemente, outros caminhos para as revoluções técnico-estéticas, desta vez, focadas na banda sonora. Destas, o mesmo Chion lamenta o quanto cineastas de prestígio ignoraram, por exemplo, o potencial do som Dolby, utilizando-o da mesma forma como faziam quando este não existia (CHION, op.cit.). 


\section{míDiA

Se no cinema as mudanças demoraram ou se mantiveram esteticamente pouco exploradas, outras alterações na sociedade relacionadas à tecnologia do som não passaram tão ao largo. Segundo Smith (2003), o fortalecimento da indústria do rádio e do seu público durante a década de 1940 é um fator considerável para o surgimento de inúmeras gravadoras e também para a atenção que a indústria cinematográfica norteamericana começou a dedicar a elas em torno da metade do século XX. As gravadoras tinham suas músicas transmitidas pelo rádio, importante meio de comunicação de massa, atingindo milhares de pessoas e auxiliando, efetivamente, na divulgação dos filmes. Para isso, além da venda de partituras, os estúdios articularam mais uma forma de promover seus filmes: chegar a um maior número de espectadores através das trilhas musicais que ocupavam as estações de rádio. Deste modo, a indústria cinematográfica desfrutou desta ampla publicidade ao ter o referente de seus filmes circulando nessas músicas.

A música popular, neste momento, transforma-se em um potente produto cultural de grande alcance, participando efetivamente de uma indústria milionária. Além do rádio, as gravadoras utilizavam também os álbuns musicais para intensificar suas vendas e aumentar seu mercado - eram criados, inclusive, álbuns específicos para filmes, prática que vigora e se intensifica nas décadas seguintes. Efetivava-se, portanto, um esquema de promoção dentro do qual o álbum explicitava sua referência ao filme, estabelecendo-se, consequentemente, como um potente produto auxiliar na publicidade da indústria cinematográfica.

Jeff Smith considera esta relação que se estreitava entre a indústria cinematográfica norte-americana e as gravadoras como proponente de uma promoção recíproca, denominada por ele como ‘cross-promotion’ (SMITH, 2003, pg. 69). O autor exemplifica ainda a enxurrada de películas que foram produzidas, a partir da década de 1950, baseadas nos músicos e nas bandas de apelo popular - como Elvis Presley e The Beatles - os quais, com sua música pop, atraiam um grande número de fãs para as salas de exibição, reconsolidando, assim, a utilização da música popular nas trilhas musicais cinematográficas. 


\section{míDiA

Smith ressalta o caráter jovem que, em maior número, constituía a audiência deste tipo de filme. Os jovens, em torno de meados do século XX, foram descobertos pelas indústrias como generosos e prolíficos consumidores. Sobre eles recaiu a atenção das indústrias na tentativa de estimulá-los a participar, permanentemente, de seus mercados. Neste contexto, o rock'n roll destaca-se por atuar como estímulo à juventude dentro da lógica capitalista na época, na qual foram criados ídolos e representantes de uma cultura jovem (o que não é exatamente diferente agora, apenas com a ressalva da não hegemonia musical do rock’n roll).

Esta aproximação entre a indústria cinematográfica e a musical confirma-se e consolida-se nos anos 1960. Neste período, acontece um movimento mais definido dos estúdios em direção à indústria fonográfica, de maneira que estes articulam a aquisição ou mesmo a criação de gravadoras ao perceberem o aumento significativo das vendas e do mercado de álbuns.

Em meados de 1958, os estúdios Warner Brothers, 20th Century Fox, e Columbia Pictures entraram para o mercado fonográfico (...). Os estúdios se beneficiaram da crescente estatura do mercado das gravadoras assim como adicionaram ângulos para exploração dos produtos dos estúdios e maior exposição para os artistas contratados. (...) No final do ano de 1960, Variety proclamou a venda de álbuns de trilha musicais como uma das mais significantes tendências do ano. (SMITH, 2003, p. 70)

Assim, alguns filmes tornaram-se referência para ilustrar a forte relação que as indústrias (cinematográfica e fonográfica) haviam estabelecido, uma vez que o casamento entre a música popular e o cinema iniciava seu caminho em direção a uma nova possibilidade de aproveitamento industrial e estético dentro do cinema Hollywoodiano - atuando em ambas as direções para provocar notável mudança no uso da música de cinema.

\section{Um som das ruas invade a tela}

Em linhas gerais, Chion define duas categorias básicas ao pensar sobre o lugar simbólico de onde a música provém em uma narrativa fílmica: música da tela (musique d'écran), quando sua fonte é visível ou inferida como proveniente de algum 


\section{míDiA

ponto da imagem e música da fossa (musique de fosse), em alusão ao local, abaixo do palco, em que a orquestra localiza-se em óperas, balés ou espetáculos teatrais. A suposta “fossa” é um lugar imaginário que contém todos os tempos e espaços e ali a música funcionaria como um observador fora do mundo narrativo que tece seus comentários sobre fatos e situações representadas (CHION, 2003). Circular entre estas fronteiras é uma característica comum a qualquer música de cinema. Portanto, vale reforçar que a dupla função a qual Chion se refere (quando a música é uma espécie de personagem em um filme) não diz respeito apenas a sua mera passagem por entre estas fronteiras, mas sim ao fato de que, além de configurar uma instância narrativa, ela encerra uma expressividade autônoma, uma voz em si, que emana de um modo particular.

Em O Invasor, a presença do rapper Sabotage - como ele mesmo - é, sem dúvida, um componente emblemático da narrativa. Ele estabelece uma inevitável relação do mundo ficcional com a realidade já que, nome importante do rap paulistano, Sabotage (Mauro Mateus dos Santos, 1973-2003) figura como um exemplo da tentativa de escapar da marginalização pelo viés musical do hip hop. Nascido na favela do Canão (Zona Sul da capital paulista), Sabotage atuou na criminalidade via tráfico de drogas quando adolescente, desvencilhando-se deste ao tornar-se rapper e "personagem" de suas próprias músicas. É ele, também quem assina boa parte da trilha musical de $O$ Invasor que, somada ao enredo e à linguagem proposta pelo diretor, formula entendimentos que, até mesmo para os que pouco ou nada conhecem sobre o gênero musical em questão, enriquece a leitura do espectador, uma vez que as canções remetem a uma espécie de crônica social, promovendo a aproximação do texto fílmico com a realidade - pela música apresentada.

Esta aproximação não é aleatória, já colocamos. Primeiro, porque o rap é o elemento "musical" de um movimento social e cultura maior, o hip hop, que surgiu em Nova Iorque na década de 1970, no Bronx, um dos bairros com imenso contingente de afrodescendentes e de imigrantes em condições político-sócio-culturais pouco favorecidas (TELLA, 2006). Neste contexto, a música do hip hop surge calcada em dois elementos que integram o movimento: a batida promovida pelo DJ (disk-jokey) e a canção falada e/ou cantada pelo Mestre de Cerimônias, que gerencia os encontros do 


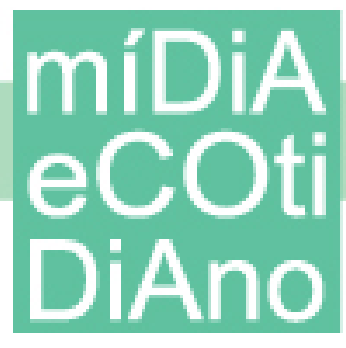

movimento, o MC (rapper). O espaço onde estes encontros acontecem é a rua, que abriga, ainda, o dançarino de break (chamado B-boy), e o grafite. Reunidos, estes quatro elementos compõem o hip hop, do qual o rap é a parte musical. Identificado como organizador dos componentes da "cultura de rua", o hip hop se viabiliza pautado pela percepção de que as gangues rivais em vez de disputarem espaço pela violência poderiam fazer da arte o seu elemento de combate, de afirmação.

Originário, portanto, das grandes metrópoles, o hip hop norte-americano, a partir dos anos 1980, dispersou-se para outros países e para outras realidades, passando a integrar o cotidiano das chamadas comunidades carentes ou, no mínimo, que vivem à margem da chamada cultura "de centro". Entre os países que incorporaram o movimento, o Brasil talvez seja um dos que mais se inspirou nos artistas norteamericanos. No entanto, ao contrário do que logo ocorreu nos Estados Unidos, aqui os rappers mantiveram-se distantes das grandes gravadoras e emissoras importantes, privilegiando os selos independentes. Uma situação decorrente, muito provavelmente, pelas letras das músicas, quase sempre permeadas por referências explícitas à miséria, ao tráfico de drogas, ao preconceito, à violência, à invisibilidade social e todo um universo de situações que são apresentados pela ótica da denúncia e, muitas vezes, da apologia ao crime, demarcando um território muito definido sobre os papéis sociais e a (falta de) expectativa da mudança de cenário. (HERSCHMANN, 2005)

A ainda resistência da indústria brasileira em abarcar e promover o rap em grande escala, como fazem os norte-americanos cujos álbuns são lançados comercialmente, esconde a própria trajetória do hip hop no país. Ela se inicia no cenário paulista, nos anos 1980, a partir da dança break que, a esta altura, já era plenamente difundida nos Estados Unidos, em especial em Nova York. Foi dali que as discotecas paulistanas a importaram, oferecendo-a, primeiramente, para o entretenimento das classes sociais mais abastadas, ou seja, bem longe da periferia. Contier comenta que o break foi introduzido no país por 'agentes sociais' (CONTIER, 2005, p. 2) que tiveram contato com a dança nos Estados Unidos e a trouxeram para o Brasil para ser introduzida nos clubes noturnos responsáveis pelo entretenimento das classes sociais de maior poder aquisitivo. 


\section{míDiA

Foi somente no final dos anos 1980 que o hip hop - enquanto um movimento integrado e organizado - figurou em São Paulo (SILVA, 1998, p. 55). Elegendo a esquina entre as ruas 24 de Maio e Dom José de Barros, em frente ao Teatro Municipal da cidade de São Paulo como um ponto de encontro, jovens menos abastados praticavam, ativamente, o break. Neste local, eles se reuniam para “(...) se entreter, treinar suas performances e trocar informações” (HERSCHMANN, 2005, p. 266). Posteriormente, as reuniões passaram a se realizar no Largo São Bento e este novo ponto tornou-se a maior referência para a cultura hip hop no Brasil, no período.

Além de difundir a dança, o espaço público promoveu também o contato com os outros elementos do movimento (rap e grafite). É só a partir deste momento que começam a despontar os primeiros rappers em São Paulo que, gradativamente se afastaram do circuito break e se organizaram em outros locais. A Praça Roosevelt marcou o início desta nova aglutinação que, no novo local, incorpora a temática racial que, aos poucos, torna-se central no movimento hip hop. (Silva, 1998).

Do centro para a periferia o movimento foi ganhando características próprias e novas nomenclaturas. Surgem as “posses” que em sua estrutura assemelhamse às reuniões que já ocorriam na Praça Roosevelt (SILVA, 1998). Se os deslocamentos descentralizam o espaço de produção e de encontro dos rappers, por outro lado permite que as questões e dificuldades cotidianas das comunidades estejam ainda mais presentes nas músicas. Servem, assim, de pano de fundo para a crítica elaborada do MC, que se apresenta sobre a batida eletrônica promovida pelo DJ.

Outro espaço que ampliou a repercussão do movimento foram as rádios comunitárias, que além de divulgarem as ações sociais realizadas pelas posses, veiculavam o panorama musical que o rap havia constituído nestes locais (SILVA, 1998, p. 75), fato que estimulou o interesse da indústria fonográfica. Mirando neste público, em 1988 a Eldorado lança o álbum “Hip Hop Cultura de Rua”, uma coletânea de grupos paulistanos que vinham se destacando desde os tempos das reuniões no metrô São Bento. Ao mesmo tempo, ocorria o fenômeno 'Racionais MC's', grupo que é um dos grandes expoentes do rap brasileiro: mesmo rejeitando a proposta de lançar álbuns “comercialmente”, ou seja, mantendo a relação com selos independentes, eles foram 


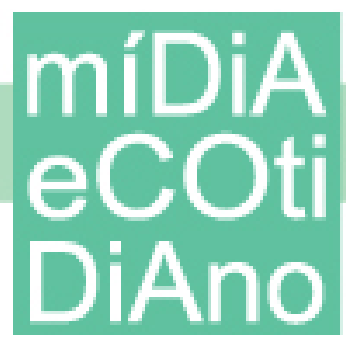

veiculados em emissoras de rádio FM e, com isso, atingiram o gosto e o consumo das classes altas.

Com esta travessia, o rap acaba se tornando um indicador claro de um determinado contexto social, travestido, portanto, de um símbolo de identidade eficiente. Em O Invasor este elo não só não é desprezado como se torna um componente essencial de legitimação dos espaços urbanos por onde o filme se desloca. Colado às ruas, ele amplia o naturalismo dos diálogos do filme, que contou com a colaboração substancial de Sabotage, principalmente nas falas de Anísio, cuja composição do personagem incorporou gírias, gestos e ações concernentes à figura de um matador. Deste modo, ao explicitar a preocupante situação existente entre as “distantes” classes sociais, o filme, somado à presença de Sabotage e de seu rap, caracteriza a pretensão de criar, de diversas formas, uma verossímil representação da experiência urbana em São Paulo.

\section{O rap e a "impressão" de realidade}

Na discussão que faz sobre representação social Becker aponta, entre outras questões relacionadas às escolhas estéticas das obras de arte, o quanto a verdade "presumida da representação artística de um fato social é um elemento essencial em nossa apreciação da obra como arte” (2009, p. 129). Em outras palavras, para o autor, as asserções assumidas pela obra artística sobre determinada realidade social contribui para seu efeito estético. No entanto, no mesmo estudo, ele vai destacar a clássica pesquisa de sociologia, Deep South, realizada por Alisson e Elizabeth Davis, que eram negros e Burleigh e Mary Gardner, brancos, em uma pequena cidade do Mississippi, Natchez, no início dos anos 1930. O objetivo da pesquisa era desvelar as desigualdades sociais no interior de grupos raciais. Para tanto, os quatro moraram durante dois anos em Natchez e ali, sem desprezar os indicadores econômicos desta sociedade, examinaram, minuciosamente, as manifestações de classe e de raça dos moradores.

O que Becker destaca particularmente do estudo é o quanto as pessoas se descreviam, umas às outras, de forma estereotipada e como eram capazes de reconhecer o grupo a que pertenciam. No entanto, apesar de identificarem classes acima e abaixo, 


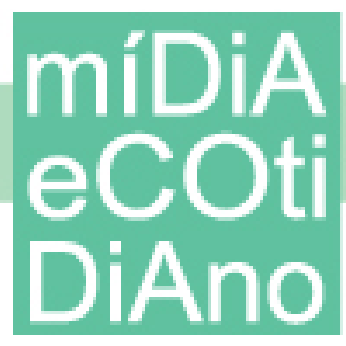

quanto maior era a distância social das outras classes, mais enevoadas se tornavam as distinções. (BECKER, op. cit., p. 172). Tal situação potencializa os indicadores já aceitos como símbolos de identidade, na medida em que desenham um fato social com maior possibilidade de identificação. Neste sentido, a música popular, e, no nosso caso, o rap, por sua própria trajetória e localização, ao ser acionado, configura um instrumento poderoso nas definições estéticas e narrativas da obra artística.

Em O Invasor, tal indicativo é corroborado por uma imagem suja, bruta e urgente, que configura o que Nagib chama de “anti-estética” (NAGIB, 2006, p. 164). Diversas escolhas do filme, tais como cenários paulistanos reconhecíveis, uso do planosequência, da profundidade de campo, da luz natural e, principalmente, da câmera na mão, fomentam uma imagem e um ritmo próximo a uma imagem documental que, aliados, aumentam o que chamamos "efeito de realidade". Por outro lado, o ritmo acelerado, promovido pelos cortes abruptos e pela sólida presença da canção, forjando uma construção estética inspirada nos videoclipes, amplifica, ao máximo, diversas sequências emblemáticas do filme. Deste modo, além de sua “anti-estética”, O Invasor confere à presença da música uma força que "explode o documento e, paradoxalmente, confere ao filme seu caráter revelatório.” (NAGIB, 2006, p. 167).

Para Nagib estas escolhas narrativas de Brant são conscientes e têm a capacidade de revelar muito do território e personagens que foca. Mesmo trabalhando no patamar do gênero, o policial, o filme não repete, apenas, os cânones, esforçando-se para investir em atualizações como o uso da linguagem do videoclipe, que localizam $O$ Invasor na esfera do contemporâneo (NAGIB, op. cit.). Neste sentido, podemos considerar que a predominância do rap configura-se como uma das principais escolhas narrativas de Brant, principalmente quando levamos em conta que o gênero musical em questão, conforme apontamos anteriormente, reflete, de fato, uma “invasão cultural” da periferia na circulação musical, tanto na capital paulista quanto em outros tantos cenários urbanos.

\section{Momentos musicais e suas “invasões” narrativas}




\section{míDiA

A discussão em torno do uso da música popular no cinema tem mobilizado diversos autores. Kassabian (2001), Smith (1998, 2003) e Lapedis (1999), que norteiam aqui nosso percurso analítico, compartilham o foco na capacidade que a trilha musical compilada - com gêneros populares - tem de estimular a leitura do espectador. A abordagem de Anahid Kassabian tenta evitar a tradicional dicotomia da relação música/cinema (como, por exemplo, paralelismo/contraponto e diegético/não diegético) e defende uma ênfase nas questões de interpretação/recepção (reading) do espectador. Ao longo do seu livro, a autora volta-se para o uso da música no cinema hollywoodiano recente e destaca especialmente a presença da música popular nos filmes (KASSABIAN, 2001).

Jeff Smith, conforme dissemos antes, debruça-se sobre a interação entre a indústria cinematográfica e a fonográfica e situa a trilha musical como um fator de “sinergia” neste contexto. Discorre sobre as compilações de música popular como ferramenta de divulgação que auxiliam na circulação do filme (através de sua trilha musical). A relação música/cinema é, portanto, retomada sob uma perspectiva mercadológica (SMITH, 1998, 2003). Já Hilary Lapedis propõe que, apesar desta evidente força comercial, as considerações sobre o mercado não devem ser as únicas abordadas para compreender o desempenho que a música popular desenvolveu no cinema. Mesmo reconhecendo a força econômica de uma indústria que é multinacional (tanto a cinematográfica quanto a fonográfica), para ela o que interessa é observar como a música popular, mesmo em sequências mínimas, pode afetar a estrutura narrativa do cinema mainstream. Além disso, a autora destaca o quanto a estética do videoclipe, em todas suas manifestações, alterou tanto o modo como a música funciona com a imagem quanto o modo como os expectadores leem os textos visual/musical” (LAPEDIS, 1999).

O que tanto Kassabian quanto Lapedis estão discutindo é justamente a potencialidade que a música popular traz à leitura do espectador, na medida em que fornece um contexto prévio “extra fílmico”, que independe das imagens. Em O Invasor um dos momentos em que se confirma a posição dos autores é a sequência em Marina leva Anísio à sua casa. Ali, após Anísio confessar seu desejo íntimo (e antigo) de morar em uma casa como esta, o rap de Sabotage, "Na Zona Sul”, funciona como uma 


\section{míDiA

“costura” para a cena seguinte, em que o matador faz o movimento inverso: leva a garota para conhecer seu mundo, em um vertiginoso passeio pelas ruas da favela. Assim, se há o choque objetivo das duas realidades apresentadas justapostas, o filme logo ganha o tom de videoclipe, pois seus registros visuais não pretendem, a priori, narrar uma história particular, uma vez que a montagem da sequência, ao abusar dos cortes abruptos e da não linearidade das ações que se desenvolvem nas imagens e das pessoas nelas inscritas, não favorece ao espectador o desenvolvimento uma narrativa fechada. “(...) Anísio conduz Marina em viagens alucinógenas pela periferia de São Paulo. (...) trata-se de travellings terrestres colecionando instantâneos documentais em sequências que nada são senão videoclipes de canções do Sabotage sobre a miserável Zona Sul e seu 'cotidiano difícil’” (NAGIB, 2006, p. 173).

O rap de Sabotage começa com fade in logo após a personagem feminina propor que eles saíssem para um passeio. Em seguida, há uma elipse temporal que já os situa no ambiente dele. O rap começa subordinado ao diálogo, ainda submisso às últimas falas da sequência anterior, sofrendo um considerável aumento do volume até que um corte seco introduz registros visuais "reais” da favela. Neste momento, a música explode na narrativa, em um primeiro plano sonoro, sem competir com outros sons ou com diálogos e, quase que instantaneamente, atrai para si a atenção do espectador que, concomitantemente, é atingido pelas imagens de uma favela.

Esta sequência emblemática do filme aproxima duas práticas que remetem a uma apreensão da "realidade”: a tomada em estilo documental e o rap. Este último, por atuar como um legítimo produto cultural do ambiente retratado que, como já comentamos anteriormente, ressoa como voz socialmente representativa e denunciativa. Ambas as práticas constroem, deste modo, um 'contexto narrativo' singular carregado de significações. Como diz Maciel (2010), o filme, ao justapor elementos visuais e musicais conduz o espectador de encontro à paisagem musical de Anísio “(...) através da interação entre "tracking shots” e "snapshot” de pessoas reais em suas atividades diárias com o estilo de música mais comumente associado aquelas área - as periferias de São Paulo.” (MACIEL, 2010, p. 222). 


\section{míDiA

O que é interessante também destacar é que estes registros 'documentais' e a linguagem do videoclipe extrapolam a narrativa do filme, dando voz à própria periferia - explicitada pela canção de Sabotage, que traz consigo um "relato” sobre a situação do "marginalizado". Neste momento, mais do que acompanhar o enredo do filme, o espectador depara-se com o cotidiano difícil do extremo sul da cidade, que abriga o “Mundo cão - decepção - constrói, transforma a pivetada da quebrada num transporte pra droga. / Zona sul: / conheço um povo todo inibido, / tanta promessa, enrolação... / acaba nisso. / De Vila Olímpia a Rocinha / Conde, Fundão / olha lá, se liga ai. / Lá está é o Canão! /(...)” 3

Sabotage, deste modo, conta/canta sobre a sua própria comunidade, o Canão ${ }^{4}$ e o rap, nesta sequência, insere o ambiente do compositor dentro da ficção, e desenha um gesto que legitima, de certa forma, a representação de um espaço social. $\mathrm{O}$ rapper denuncia, entre outras coisas, uma ácida relação com a polícia, retratada como corrupta e violenta. Este e outros fatos - rimados em batidas rítmicas pulsantes - podem ser harmoniosamente relacionados ao contexto conturbado e dissonante que o filme narra.

No entanto, na mesma sequência é possível observar o rap funcionando, também como "comentário" narrativo do filme. Isto ocorre porque enquanto o casal circula pela cidade, o rap, sem que se tenha certeza de sua fonte, transita entre as dimensões diegética e não-diegética, o que lhe dá ambiguidade: a mesma música pode ser um elemento "natural" ao ambiente retratado (principalmente quando entendida como proveniente do aparelho de som do carro de Marina) e funcionar como “comentário”. Ainda sobre este uso da música que parece situar-se "entre” fronteiras, Kassabian ressalta que, mais importante do que esta flutuação em si é o fato de que canções que operam desta maneira, em filmes, deslocam a atenção do espectador para além de suas próprias caraterísticas em decorrência desta habilidade de combinar estímulos e processos narrativos diversos (KASSABIAN, 2001, p. 42-43).

O segundo "momento musical” que queremos destacar é a "apresentação" de Sabotage, que canta o rap "O invasor”. Nesta sequência, Anísio literalmente nos

\footnotetext{
${ }^{3}$ Trecho da música "Na Zona Sul”, composta por Sabotage e Cascão.

${ }^{4}$ Favela do Canão - comunidade carente da Zona Sul de São Paulo onde o rapper Sabotage nasceu.
} 


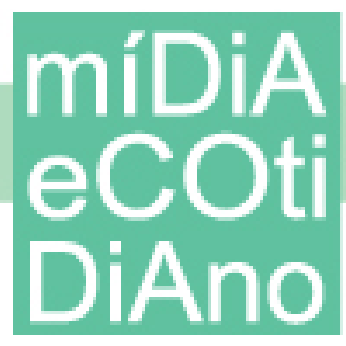

apresenta Sabotage que, atuando como o rapper Sabotage, vai, a convite do invasor, até à construtora em busca de patrocínio para a gravação de seu álbum. Sabotage diz, no início da sequência, que foi ao encontro dos engenheiros devido ao mandato de Anísio, que neste momento deixa evidente seu poder sobre Ivan e Giba. Enquanto tudo isto ocorre, é o rap “O Invasor”, de autoria de Sabotage (que o canta) em parceria com Rica Amabis e Tejo, que toma a tela.

A presença de Sabotage, além de permitir que o seu rap invada a diegese, ilustra uma aversão da “classe alta” para com a figura/estereótipo do excluído, explicitada pela interpretação dos atores. A indumentária característica da favela destoa do ambiente da elite, auxiliando na "irrupção do real” (NAGIB, 2006, p. 174.) que a figura do rapper "negro, magro e desdentado" (ibid.) dispõe ao fornecer informações de todo um contexto ao filme. Para Maciel (op.cit, p. 223) a cena funciona como merchandising da música de Sabotage ao mesmo tempo em que inclui uma rejeição elitista, pois Giba interrompe a performance do rapper, que não fica passivo: "mano, o cara tá desgostoso da vida e não curte o rap”.

A entrada em cena de Sabotage é similar à do rapper em palco. Ali ele profere sua canção denunciativa e altera momentaneamente o fluxo narrativo, uma vez que a atenção, neste momento, converge para a sua figura e para seu rap. Com a interrupção da performance, os engenheiros, sem alternativas senão a de ceder às vontades de Anísio, concedem a quantia requerida pelo chantagista e, deste modo, cada vez mais o matador “nivela” as relações entre eles, pautado pelo desespero dos personagens que permite acionar o desejo do matador.

\section{Conclusão}

A crise social revelada pelo filme ancora-se no testemunho e na legitimidade que o rap - enquanto movimento cultural que realmente integra o cotidiano das comunidades retratadas - promove. Mesmo para aqueles que não conhecem profundamente suas origens e proposta, o rap consegue, via mensagens explícita nas letras, contribuir para que a narrativa cerque o tema de forma mais flagrante. Além disso, a mídia já lhe deu espaço suficiente para que o estilo musical surja como símbolo 


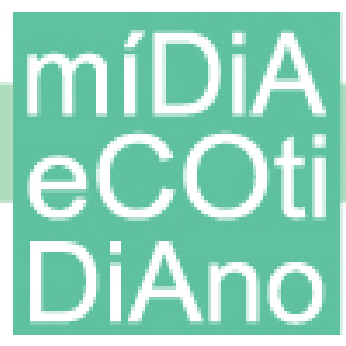

identitário, ao mesmo tempo em que, paradoxalmente, pela ampliação que promove, sirva também para iniciar o processo de corrosão deste mesmo sentido. O que não é novidade, se pensarmos quantos outros movimentos, nas mais diversas artes, vivenciaram esta trajetória.

Realizado no início do século, em 2001, e adaptado do romance de Marçal Aquino, de mesmo nome, O Invasor revela, sobretudo, as escolhas estéticas de Beto Brant - em direção ao "efeito de realidade” - que desenham seu filme. Nesta trilha, tanto a música como a forte figura "real” do rapper Sabotage, revelam a sensibilidade do diretor em relação aos signos identitários que cercam as classes sociais naquele momento. Além disso, o filme desvela a continuidade da sinergia entre as produções fonográficas e cinematográficas uma vez que, após O Invasor Sabotage tornou-se muito mais conhecido. ${ }^{5}$

O fato é que o rap, no filme, soa como uma espécie de "nivelamento" resultante de um caótico desnivelamento social. O exemplo mais evidente deste deslocamento é a canção "Vai Explodir”, do Pavilhão 96 , a única que é apresentada integralmente no filme, quase na sequência final. Ela surge colada a um agora paranoico Ivan, totalmente desestruturado psicologicamente, devido à desconfiança de que será o próximo a ser aniquilado por Giba e Anísio. Com a situação emocional agravada por descobrir a real identidade de Cláudia, uma prostituta contratada por Giba para vigiá-lo, leva-o a buscar, insanamente, o sócio. Após bater o carro e inutilizar o veículo, Ivan é obrigado a percorrer uma avenida a pé, na periferia.

Mais uma vez a estética ruidosa e suja da imagem, na qual predomina uma luz esverdeada, auxilia na construção da essência da cena, corroborando com a sensação desesperadora em que se encontra Ivan. Visivelmente atormentado, totalmente sozinho e sem perspectivas, o empresário parece sucumbir à esquizofrênica confissão que o rap promove. Em simbiose com a ação, o rap resume tanto o enredo, que chega próximo do fim, quanto uma perspectiva negativista que os contrastes sociais urbanos promovem:

\footnotetext{
${ }^{5}$ Infelizmente, em 2003 Sabotage voltou a ser destaque na mídia por ser sido brutalmente assassinado por um traficante perto de sua casa, na zona sul de São Paulo.

${ }^{6}$ Do álbum “Se Deus Vier, Que Venha Armado”, de 1998, lançado pela Paradoxx Music.
} 
Eu mando fogo / Vamos ver quem é que pode / O som é dinamite / Só comove quando explode / Eu vou falar pra quem se julgam os tais / Arrumo o escarcéu / A nossa rima eficaz / Vem me pegar / Na área frente a frente ou no beco / Corre na veia / O hip hop som dos guetos / Eu vejo um garoto / Pé descalço está com fome / Eu tomo aqui as dores / Vamos ver quem é que se move / Enquanto a ONU só fala de paz / Do outro lado / Mortes, crimes, desabafos, tem demais / Já vi pior / Face a face eu te falo / Não disfarce / Não disfarce do relato / Boom! A bomba vai explodir / Ninguém vai te acudir Sociedade destrói sua vida / Capitalismo por aqui suicida / Entenda, entenda/ $(\ldots)^{7}$

A sonoridade do Pavilhão 9 também é ruidosa, resultante da mescla do rap com elementos do rock hardcore, e o tom denunciativo das vozes, somado ao conteúdo falado, funciona como uma espécie de voz narrativa que comenta muitas das situações encenadas no filme (a ganância capitalista, a exclusão social, a injustiça, a ilegalidade, entre outras), enquanto vemos Ivan, num plano-sequência, caminhando a esmo. Atropelada pelo refrão da canção, cujo volume é mais alto, a narrativa explode e suscita a percepção do espectador para além do desespero do personagem, motivando um momento de contemplação, estratégia que sugere uma participação ativa na formulação de sentidos.

Enfim, o que se pretendeu demonstrar, destacando os exemplos de $O$ Invasor que exploram, de diferentes formas, os comentários que emergem através das músicas, aliadas ao seu contexto específico (gênero, letra e seus intérpretes) é o quanto a música popular, fortemente presente no cotidiano, pode ser uma aliada potente na narrativa fílmica. No filme de Beto Brant, a trilha musical carrega, como dissemos, um discurso político-social e isto se dá, sobretudo, porque o rap o reitera ao mesmo tempo em que transmite um contexto prévio e particular aos espectadores, motivando uma constante colagem de novas informações às imagens. Tal diagnóstico sintoniza-se ao que afirma Lapedis, para quem a música popular serve como elo entre os espectadores, fazendo com que as leituras do texto operem tanto relacionadas à diegese, num nível que ela denomina de "interpessoal”, quanto fora dela, de acordo com contextos coletivos e sociais, construindo o que ela refere como "nível meta-diegético"

\footnotetext{
${ }^{7}$ Trecho de "Vai Explodir”, do Pavilhão 9.
} 


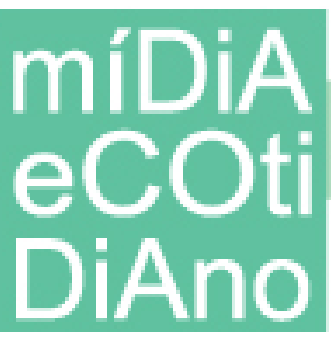

(LAPEDIS, 1999, p. 378). Há, nesta percepção, um universo de significações que, cada vez mais, corroboram com múltiplos níveis de interpretação que, a nosso ver, dão à música popular e ao cinema, perspectivas sólidas e potentes que merecem ser exploradas.

\section{REFERÊNCIAS BIBLIOGRÁFICAS:}

BECKER, Howard S. Falando da Sociedade. Rio de Janeiro: Zahar, 2010.

CHION, Michel. A Audiovisão - Som e Imagem no Cinema. Lisboa: Texto\&Grafia, 2008.

CHION, Michel. Un art sonore, le cinema. Paris: Cahiers du Cinéma, coll. Essais, 2003.

CONTIER, A. D. “O Rap brasileiro e os Racionais MC's”. In: Revista Eletrônica Scielo, 2005. Revista Eletrônica Scielo. p. 1-12, 2005.

HELLER, Agnes. O Cotidiano e a História. São Paulo: Paz e Terra, 2008.

HERSCHMANN, Micael. O funk e o hip hop invadem a cena. Rio de Janeiro:

Editora UFRJ, 2000.

KASSABIAN, Anahid. Hearing Film: Tracking Identifications in Contemporary Hollywood Film Music. New York/London: Routledge, 2001.

LAPEDIS, Hilary. "Popping the question: the function and effect of popular music in cinema” In: Popular music - vol. 18/3, Cambridge University Press, 1999.

MACIEL, Katia A. "Mediações culturais no filme Invasor: Interseções entre a música e o cinema” In: Contracampo (UFF), v. 21, p. 217-230, 2010.

NAGIB, Lúcia. “A distopia urbana”. In: A utopia do cinema brasileiro: matrizes, nostalgias e distopias. São Paulo: Cosac Naify, 2006, p. 159-178.

SILVA, José C. Gomes. Rap na cidade de São Paulo: Música, Etnicidade e Experiência Urbana. Campinas, 1998: Tese (Doutorado no Instituto de Filosofia e Ciências Humanas - Universidade Estadual de Campinas).

SMITH, Jeff. "Banking on film music: structural interactions of the film and record industries” In: DICKSON, Ray. Movie music - the film reader. London: Routledge, 2003. 


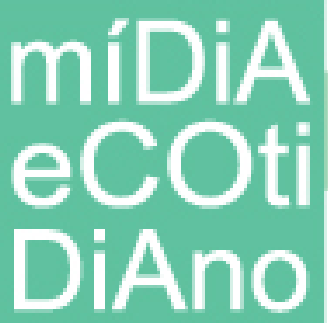

SMITH, Jeff. "Did they mention music? Toward a theory of popular film music"In: The Sounds of Commerce: marketing popular film music. New York: Columbia University Press, 1998.

TELLA, Marco Aurélio Paz. “Reação ao estigma: o rap em São Paulo” In: Revista Enfoques, Rio de Janeiro, v.5, p. 40-61, 2006. 